\title{
ZJAWISKO PROSTYTUCJI - POMIĘDZY KONIECZNOŚCIĄ A TABU?
}

\begin{abstract}
Streszczenie. Prostytucja jest zjawiskiem wywołującym skrajne emocje w dyskursie. Stereotypy i mity, w które obrósł ten proceder, przyćmiewają jego rzeczywisty obraz. Istotna jest zatem refleksja na temat przyczyn i konsekwencji prostytucji. Negatywna konotacja wyrażeń, określających osoby świadczące usługi seksualne, wpływa na rozumienie i kształtowanie stereotypów. Istnienie prostytucji wystawia na próbę tradycyjne pojęcia definiujące seksualność człowieka. Z jednej strony jawi się jako konieczność, a z drugiej jako wentyl bezpieczeństwa społeczeństwa. Jakie są zatem jej granice i jak oddzielić to, co mieści się w akceptowalnych społecznie normach, a co nie. Wątpliwości związane z legalizacją prostytucji pokazują, jak niejednoznaczne jest to zjawisko.
\end{abstract}

Słowa kluczowe: prostytucja, stereotypy, legalizacja prostytucji, usługi seksualne, sex-workers, edukacja seksualna.

\section{WSTĘP}

Współczesne przemiany w zakresie seksualności człowieka sprawiają trudności w jednoznacznym wyznaczeniu tego, co mieści się w normach społecznych, a co je przekracza. Kontrowersje wokół tematu seksualności wystawiają na próbę tradycyjne pojęcia definiujące intymność człowieka. Prostytucja wystawia na próbę cenione społecznie wartości i zdaje się stać do nich w opozycji, skrajności skupiają się w niej jak w soczewce, pokazując prawdziwy stosunek społeczeństwa do sfery seksualnej. Osoby uprawiające prostytucję żyją w cieniu mitów i stereotypów na swój temat, doświadczając przy tym społecznej stygmatyzacji i odrzucenia. Czy jednak ten ostracyzm nie jest zakłamaniem? Prostytucja jest zjawiskiem, które występuje w każdej kulturze od wieków. Należy zatem zadać pytanie, dlaczego tak „hańbiące i niegodne” zajęcie ciągle funkcjonuje w społeczeństwie? Pomimo podejmowanych prób nie udało się go unicestwić. Prostytucja jest faktem. Faktem ujmowanym w kategorii patologii społecznej, który nie powinien pozostawać obojętny dla ustawodawcy. Na prostytucję można spojrzeć z perspektywy statusu prawnego nierządu jako czynności, statusu prawnego prostytutek oraz zjawiska kryminogennego (środowiska, w jakich rozwija się prostytucja, prostytutka jako ofiara oraz konsekwencje prostytucji). Stereotypy i mity na temat

* Uniwersytet Śląski, Wydział Prawa i Administracji, Katedra Teorii i Filozofii Prawa, m.drapalska@gmail.com. 
nierządu powodują szkodliwe konsekwencje etyczne - prostytutki są postrzegane jako osoby niedoznające krzywdy lub godzące się na jej doznawanie (volenti non fit iniuria). Negatywne emocje wokół zjawiska prostytucji spowodowały uśpienie czujności ustawodawcy. Prostytucja jest w Polsce legalna, ale nie jest regulowana prawnie. Czy zatem legalność znaczy dowolność lub obojętność ustawodawcy?

\section{POJECIE PROSTYTUCJI I JEGO EWOLUCJA}

Prostytutki zawsze funkcjonowały na marginesie życia społecznego. Negatywny odbiór społeczny prostytucji znajduje odzwierciedlenie w słowach wyrażających pogardę i niesmak wobec uprawiających tę profesję: dziwki, córy Koryntu, hetery, kokoty, nierządnice, ladacznice, kobiety lekkich obyczajów, lafiryndy, służebnice Wenery (Warylewski 2017, 1292). Jak trafnie wskazuje Monika Płatek:

Słowa nadają nie tylko zjawiskom i rzeczom nazwę. Niosą również kaliber emocji, wspomnień, asocjacji, zarówno uświadomionych, jak i nieuświadamianych. Rzutują na nasze nastawienie do tematu, pojęć, zjawisk. Niekiedy jesteśmy tego świadomi, często jednak tego nie kontrolujemy. [...] Skoncentrowanie na negatywnych konotacjach słowa „prostytutka” pozwala umknąć bądź nie narodzić się refleksji, jakie jest źródło tak degradujących skojarzeń (Płatek 2014, 226-227).

Nazwy wyrażające zjawisko prostytucji mają ogromny ładunek negatywnych emocji, które podkreślają brak godności osób prostytuujących się. To, jak ujmujemy pojęcia, wpływa na to, jak rozumiemy i odczuwamy dane zjawiska.

W polskim ustawodawstwie nie ma definicji legalnej pojęcia prostytucji. Pierwsze próby ujęcia tego zjawiska można odnaleźć w ustawodawstwie międzywojennym. W art. 23 instrukcji dla lekarzy i urzędników urzędów i punktów sanitarno-obyczajowych z dnia 4 kwietnia 1919 r. zdefiniowano osobę zawodowo uprawiającą nierząd jako tę, „która sprzedaje się wielu osobnikom w krótkich odstępach czasu (w ciągu tego samego dnia lub tygodnia)". Warto również zwrócić uwagę na projekt polskiej ustawy o zwalczaniu nierządu z 1938 r., zgodnie z którym „nierząd to obcowanie płciowe z dowolną liczbą osób w celach zarobkowych" (art. 1 projektu; za Lipska-Toumi 2014, 92-93). W ustawie z dnia 6 czerwca 1997 r. - Kodeks karny (Dz.U. z 2018 r., poz. 1600) występuje pojęcie prostytucji, ustawodawca zrezygnował z posługiwania się jej pejoratywnym odpowiednikiem „nierząd”, którego używał zarówno w art. 174 ustawy z dnia 19 kwietnia 1969 r. - Kodeks karny (Dz.U. z 1969 r. Nr 13, poz. 94), jak i w rozdziale XXXII (art. 203, 205, 208-211) rozporządzenia Prezydenta Rzeczypospolitej z dnia 11 lipca 1932 r. - Kodeks karny (Dz.U. z 1932 r. Nr 60, poz. 571). W literaturze podjęto bardzo wiele prób określenia tego zjawiska, jednak, z uwagi na jego złożoność i różnorodność, nie doprowadziły one do stworzenia uniwersalnej, prawnej definicji pojęcia. Problemy z jej sformułowaniem wynikają także 
z tego, że poszczególni autorzy kładą nacisk na inne aspekty. Z biegiem czasu poszczególne elementy dezaktualizują się, przykładowo przypisywanie cech prostytucji tylko kobietom, czy przypadkowość partnerów. Można jednak dostrzec powtarzalność niektórych, takich jak motyw działania związany z realizacją celu ekonomicznego z jednej strony, a z drugiej - zaspokojenie popędu seksualnego, zmiana partnera seksualnego, uczuciowa obojętność, wynagrodzenie, a także motyw ,świadomości prostytutki, że zajmuje się ona odpłatnym świadczeniem usług seksualnych - i właśnie ten element odróżnia prostytucję od rozwiązłości seksualnej” (Poznańska 2005, 996). Wybitny znawca tematyki, Kazimierz Imieliński, ujmuje prostytucję jako oddawanie własnego ciała do dyspozycji większej liczby osób w celu osiągnięcia przez nie zadowolenia seksualnego i pobierania za to wynagrodzenia materialnego. Podkreśla, że seks ma znaczenie dla człowieka zarówno w wymiarze biologicznym, jak i społecznym oraz psychologicznym. Prostytucję charakteryzuje zaspokojenie jedynie sfery biologicznej, tj. dostarczenie odczucia odprężenia, ulgi, rozładowania napięcia seksualnego. Z punktu widzenia osoby prostytuującej się kontakt z klientem nie może spełniać żadnej funkcji właściwej dla seksu, dzięki czemu może ona traktować seks jako swoisty rodzaj pracy, umożliwiający zarobkowanie, a nie akt seksualny, którego celem jest osiągnięcie rozkoszy (Imieliński 1990, 5-6).

Negatywne konotacje wokół pojęcia prostytucji uzasadniane są przez istniejące stereotypy. Z jednej strony stereotypy funkcjonują $\mathrm{w}$ umyśle jednostki, z drugiej stanowią integralną część struktury społecznej (Stangor, Schaller 1999, 13). Stereotypy to twory świadomości odpowiadające na potrzeby psychiczne człowieka i pozwalające mu porządkować rzeczywistość. Człowiek bowiem w percepcji rzeczywistości kieruje się zasadą ekonomiki - dokonuje identyfikacji pewnej istotnej cechy, po czym porządkuje zjawisko do określonej, znanej wcześniej kategorii. Poznajemy świat zanim go ujrzymy i realnie doświadczymy - te „wyprzedzenia” rządzą naszym procesem poznania (Schaff 1981, 51-52). Człowiek ma naturalną skłonność do postrzegania osób czy przedmiotów jako mających wspólne atrybuty, co pozwala mu łatwiej poznać otaczający świat. Uporządkowane myślenie, kategoryzowanie określonych pojęć daje ludziom poczucie bezpieczeństwa. Konsekwencją uproszczenia obrazów rzeczywistości jest często ich zniekształcenie (Nelson 2003, 25). Ponadto należy wskazać, iż nieodłącznym elementem stereotypu jest komponent emocjonalny. Świat kobiet i mężczyzn jest odbierany społecznie jako wzajemnie się wykluczający. To, co jest męskie, nie może być kobiece, a to, co jest kobiece, nie może być męskie. Ma to związek ze stereotypami dotyczącymi ról płciowych. Aktywność w sferze seksualnej mężczyzn jest postrzegana jako coś naturalnego. O mężczyznach, którzy mają wiele partnerek i bogate życie seksualne często mówi się w kategoriach żartobliwych, czy nawet $\mathrm{z}$ podziwem. Kobieta w sferze seksualnej ma być bierna, a mężczyzna aktywny. Sfera seksualności kobiety jest zamykana w schemacie: 
pasywna, cnotliwa, niezainteresowana seksem, nieprowokująca, wierna jednemu partnerowi, pragnąca realizować się jako matka. O kobietach, które nie spełniają wzorców wynikających z ich kulturowych ról społecznych, mówi się często w sposób pejoratywny - łatwa, puszczalska, bez zasad, ta, która „się nie szanuje”. Można zatem podzielić kobiety na „porządne” i „ladacznice". Zainteresowanie seksem, czerpanie z niego przyjemności, otwartość na nowe doznania erotyczne, zmiana partnerów i aktywne ich poszukiwanie są domeną tych „drugich”. Zgodnie z tym podziałem do kategorii ladacznic zaliczymy prostytutki, które z założenia uprawiają seks za pieniądze. Seks jest traktowany jako usługa pozbawiona więzi uczuciowej, sprowadzająca się do realizacji funkcji biologicznej (popędu płciowego). To właśnie prostytucja skupia wszystkie negatywne obrazy seksualności kobiecej i seksualności jako takiej (Dec-Pietrowska, Walendzik-Ostrowska 2014, 298). Szkodliwość stereotypów na temat prostytucji przejawia się w pomniejszaniu zła, doznawanego przez osoby prostytuujące się (stereotyp o tym, że prostytutki nie można zgwałcić). Stereotypy pozwalają usprawiedliwiać negatywną postawę wobec tych kobiet. Jak bowiem można przejawiać współczucie, zrozumienie czy chęć pomocy komuś o takich cechach. Ponadto negatywnej ocenie moralnej podlegają jedynie osoby prostytuujące się, a nie korzystające z tych usług, co może wynikać z podwójnych standardów etycznych wobec zachowań seksualnych kobiet i mężczyzn (Walendzik-Ostrowska 2006, 35). Oznacza to również ciche przyzwolenie na korzystanie z usług seksualnych. To właśnie popyt na usługi seksualne powoduje, iż prostytucja ciągle funkcjonuje w społeczeństwie - to nie prostytutki są odpowiedzialne za istnienie prostytucji, a korzystający $\mathrm{z}$ ich usług. Gdyby nie było popytu, prostytucja już dawno przestałaby istnieć. Popyt określa podaż, a nie odwrotnie. Takie same prawa określają funkcjonowanie rynku usług seksualnych, które są sprzedawane, ponieważ są chętni, aby z nich skorzystać. Istotne jest zatem rozpoznanie przyczyn korzystania z prostytucji. Mogą one wynikać z trudności w nawiązywaniu kontaktów interpersonalnych, braku umiejętności komunikacji intymnej w związku, ciekawości, chęci zaspokojenia potrzeb seksualnych w przypadku niemożności ich realizowania w normalnym związku (np. z powodu oziębłości lub problemów seksualnych partnerki, niepełnosprawności). Usługi świadczone przez prostytutki są odpowiedzią na te potrzeby. Korzystanie z nich nie rozwiązuje problemów, może nawet spowodować ich pogłębienie. Są to przyczyny niezależne od osób oferujących takie usługi, a związane z głębokimi przemianami w zakresie współczesnych relacji międzyludzkich (tamże, 36-37). Stereotypy na temat prostytucji powodują również stygmatyzację prostytutek i ich ukrywanie się - prowadzenie tzw. podwójnego życia (Welskop 2009, 230-231). Stereotypy na temat prostytucji szkodzą kobietom świadczącym usługi seksualne, ale również całemu społeczeństwu. $Z$ jednej strony wzmacniają ich już i tak negatywny wizerunek, a z drugiej oddziałują na nie same, dając przy 
tym pozwolenie na wyrządzanie im krzywdy. Negatywna atmosfera wokół zjawiska prostytucji powoduje, że osoby prostytuujące się niechętnie szukają pomocy $\mathrm{w}$ instytucjach państwowych w obawie przed brakiem zrozumienia, stygmatyzacją czy lekceważeniem. Stereotypy, w które prostytucja obrosła mogą być, i często są, źródłem uprzedzeń, a także mogą stanowić podstawę do dyskryminacji, przejawiającej się w konkretnych, wrogich zachowaniach. Konieczne jest zatem uzdrowienie dyskursu na temat seksualności człowieka i odarcie go z mitów i stereotypów. Obalaniu mitów dotyczących prostytucji i kobiet w niej pracujących służyłyby przede wszystkim działania edukacyjne. $\mathrm{O}$ wiele trudniejsze jest jednak zmodyfikowanie stereotypów, które już funkcjonują w dyskursie (Dec-Pietrowska, Walendzik-Ostrowska 2014, 308-309). Pierwszym krokiem powinny być zmiany językowe. Osoby prostytuujące się należałoby zatem określać jako sex-workers, czyli 'osoby świadczące usługi seksualne'. Nazwa ta nie zawiera negatywnych konotacji, jest neutralna, nie piętnuje ani nie uwypukla damskiego charakteru prostytucji. Przyjęcie takiej systematyki pojęciowej nie oznacza, że prostytucję uznaje się za zjawisko pozytywne i pożądane. Zmiana pojęciowa jest pierwszym krokiem na drodze do przywrócenia osobom świadczącym usługi seksualne należnego im szacunku i godności (Walendzik-Ostrowska 2006, 39).

W rozważaniu charakteru zjawiska istotne znaczenie ma geneza czynników wpływających na prostytuowanie się. W tym zakresie można wyróżnić trzy teorie: biologiczno-psychologiczną, społeczno-ekonomiczną, kulturowo-środowiskową.

Nurt biologiczno-psychologiczny opiera się na założeniu, zgodnie z którym osoby prostytuujące się posiadają predyspozycje charakterologiczne oraz biologiczne, skłaniające do wykonywania tych czynności oraz do korzystania z tych usług. Cesare Lombroso ukuł pojęcie „urodzonej prostytutki”, które oznacza, że kobieta rodzi się zarówno z predyspozycjami anatomicznymi, jak i zwyrodnieniami psychicznymi, powodującymi u niej stan moralnego zobojętnienia (za Charkowska 2010, 40). Inne koncepcje tego nurtu dowodzą, że przyczyny prostytuowania się oparte są na psychopatycznych cechach osobowości, takich jak zmysłowość, niezdolność do panowania nad sobą, ale także niedorozwój umysłowy, alkoholizm rodziców. Nurt ten nie jest współcześnie uznawany (tamże, 40-43).

Nurt społeczno-ekonomiczny upatruje przyczyn prostytucji w złych warunkach bytowych jednostki. Szczególnie motyw ekonomiczny miał znaczenie w Polsce w okresie dwudziestolecia międzywojennego oraz po wojnie. Współcześnie jednak prostytucja nie odznacza się elementem przymusu, ale wyboru. Rozwija się zarówno w najniższych warstwach społecznych, jak i w najwyższych. W celu wyjaśnienia współczesnego zjawiska prostytucji można posłużyć się teorią dewiacji oraz teorią neutralizacji. Zgodnie z teorią dewiacji, gdy jednostka napotyka problemy w realizacji sukcesu zawodowego, poszukuje wówczas grup, od których uzyska wsparcie oraz moralne uzasadnienie dewiacyjnych zachowań. 
Jednostka nie chce rezygnować ze swoich celów, jest na tyle zdeterminowana, aby realizować je w drodze zachowań z zakresu patologii społecznej. Racjonalizuje przy tym swoje wybory, pozostawiając kwestie moralne na drugim planie. Teoria neutralizacji stworzona przez Greshama Sykesa i Davida Matza zakłada, że w społeczeństwie funkcjonuje system wartości oficjalnych oraz nieoficjalnych, które są uznawane przez społeczeństwo za dewiacyjne (tamże, 48). Jednostka, podejmując działania dewiacyjne, dokonuje różnego rodzaju samousprawiedliwień (technik neutralizacji), poprzez które kwestionuje swoją odpowiedzialność za własne działania i ich szkodliwość. Osoba prostytuująca się stosuje mechanizmy obronne, takie jak racjonalizacja, zaprzeczenie czy wycofanie (Charkowska 2010, 48-49; Sztobryn-Giercuszkiewicz 2004, 46-47). Dzisiaj prostytucja nie jest uwarunkowana jedynie trudną sytuacją finansową, ale chęcią podniesienia swojego statusu materialnego w szybki sposób.

Nurt kulturowo-środowiskowy skupia się na analizie przyczyn powstawania prostytucji, która w tym ujęciu jest kontynuacją kobiecej roli społecznej, polegającej na zaspakajaniu potrzeb innych osób. Zgodnie z założeniami tego nurtu środowisko wychowawcze oraz rodzinne ma największy wpływ na genezę prostytucji. Jako przyczyny upatruje się oddziaływania wychowawcze opiekunów, ich stosunek do seksualności (np. tolerancję wobec osób utrzymujących kontakty seksualne $\mathrm{z}$ wieloma partnerami), złe pożycie małżeńskie rodziców, a także wpływ zdemoralizowanych rówieśników. Badania dziewcząt, które trudnią się prostytucją, wykazały, iż często postrzegają one relacje damsko-męskie jako pozbawione wyższych uczuć, a ich wizja świata jest pesymistyczna i pozbawiona emocji (Charkowska 2010, 52-53).

Przyczyny prostytuowania się mogą być różnorodne, są trudno uchwytne i w istocie zależne od partykularnego przypadku. Duże znaczenie mają konsekwencje uprawiania prostytucji. Prostytucja nie jest zjawiskiem więziotwórczym - dostarcza chwilowych, silnych doznań, nastawionych na szybką realizację potrzeby seksualnej. Być może jest przejawem osamotnienia człowieka we współczesnym świecie. Prostytucja, nie naruszając konkretnego dobra, może być oceniania tylko z perspektywy obyczajowości, która nakazuje, by obcowaniu płciowemu towarzyszyły wyższe uczucia. Kanalizuje zaspokajanie potrzeb seksualnych poza związkami opartymi na więzi uczuciowej. Osoby niebędące w takich związkach byłyby skazane na sublimację popędu seksualnego. Prostytucja wywołuje negatywne konsekwencje dla osób ją uprawiających: w wymiarze społecznym - stygmatyzację, marginalizację, dyskryminację; fizycznym - pobicia, kradzieże, gwałt, doświadczenia agresji, bólu, ryzyko zarażenia wirusem HIV; psychicznym - upokorzenie, niskie poczucie własnej wartości, oziębłość seksualną, niechęć do swojego ciała (Gardian-Miałkowska 2013, 135-136). Osoby prostytuujące się podejmują ryzykowane zachowania - mogą zostać ofiarami nadużyć zarówno ze strony klientów, jak i sutenerów. Należy pamiętać, że przemoc nigdy nie jest usprawiedliwiona 
bez względu na rodzaj wykonywanej działalności. Jak wskazał Sąd Najwyższy (wyr. z dnia 7 czerwca 1971 r., sygn. II KR 86/71), ,nawet kobiety uprawiające zarobkowo nierząd korzystają z ochrony karno-prawnej w zakresie seksualnym". Przekonanie o tym, iż prostytutki nie można zgwałcić, jest błędne. Zgwałcenie osoby trudniącej się prostytucją jest możliwe tak samo, jak zgwałcenie każdej innej osoby. Należy jednak zwrócić szczególną uwagę na problem tego aktu przemocy wobec osoby świadczącej usługi seksualne jako swoistej postaci gwałtu. Skoro prostytucja jest akceptowana społecznie (jest przyzwolenie na jej istnienie), państwo przy użyciu przepisów prawnych powinno zapewniać ochronę osobom, dzięki którym prostytucja jako taka funkcjonuje, ze względu na szczególne niebezpieczeństwa, które może powodować uprawianie tej ,profesji”. Nie chodzi o to, aby osoby takie miały lepszą ochronę prawną, ale nie ma żadnego powodu, aby była ona gorsza (Krajewski 2012, 71). Zjawisko prostytucji podlega dynamicznym przemianom, co wpływa na rozwój jej nowych form (od tzw. gwardzistek po „gruzinki”, galerianki, blachary, razówki). Prostytucja może przybierać formę długotrwałej relacji, która wiąże się nie tylko z zaspakajaniem popędu seksualnego. Od osób świadczących płatne usługi seksualne wymaga się wykształcenia, obycia, dobrego wyglądu (sponsoring). Ponadto istotne znaczenie ma poszerzanie kręgu osób trudniących się tym zajęciem, a w szczególności rozwój prostytucji w środowisku nieletnich (tzw. świnki).

Oceniając prostytucję, należy „otrząsnąć się” z emocjonalnych konotacji $\mathrm{z}$ nią związanych, ponieważ przyćmiewają istotę zjawiska i zaistniałe $\mathrm{w}$ jego ramach problemy. Po pierwsze, ważne jest rozpoznanie przyczyn prostytucji, które są głęboko zakorzenione w społecznych konwencjach i przemianach w zakresie relacji międzyludzkich (osamotnienie, nieumiejętność tworzenia trwałych więzi emocjonalnych). Po drugie, rozpoznanie odmitologizowanych konsekwencji funkcjonowania prostytucji - zarówno z perspektywy osób prostytuujących się, jak i całego społeczeństwa, pozwoli na redukcję szkód związanych z jej uprawianiem, a także na skuteczną realizację programów profilaktyczno-pomocowych, kładących nacisk na bezpieczne warunki świadczenia usług, skierowanych do osób, które je oferują, a także do osób zagrożonych podjęciem się takiej formy zarobkowania (Gardian-Miałkowska 2013, 148-149). Czy konieczne jest zatem definiowanie prostytucji? Clara non sunt interpretanda? Racjonalizując i pozbywając się uprzedzeń oraz stereotypów, można inaczej spojrzeć na prostytucję. Jest to usługa seksualna o charakterze umowy cywilnoprawnej, która wymaga istnienia dwóch stron. Nie jest jednak zwyczajną usługą, wymaga bowiem zaangażowania usługodawcy - zaspokojenia potrzeby seksualnej, intymności, rozmowy, zrozumienia, obecności. Można ją zrealizować jedynie wówczas, gdy jest usługobiorca (Płatek 2014, 236-238). Należy przy tym szczególnie podkreślić dobrowolność, wynikającą z dojrzałej i nieprzymuszonej decyzji, będącą fundamentem usługi seksualnej. 


\section{PROSTYTUCJA W POLSKIM USTAWODAWSTWIE - POMIĘDZY STYGMATYZACJĄ A MILCZĄCYM PRZYZWOLENIEM}

W Kodeksie karnym z 1932 r. kwestie związane z uprawianiem prostytucji zostały uregulowane w rozdziale XXXII, zatytułowanym „Nierząd”. Przepis art. 207 k.k. z 1932 r. kryminalizował ofiarowanie się osobie tej samej płci do czynu nierządnego z chęci zysku, czyli prostytucję homoseksualną. Nie sankcjonowano prostytucji heteroseksualnej. Wyjątkowo czyny te mogły być kryminalizowane pośrednio - na podstawie art. 213 k.k. z 1932 r., który stanowił, że zabronione jest dopuszczenie się czynu nierządnego publicznie lub w obecności małoletniego poniżej lat 15. Stanowił on więc w istocie odpowiednik dzisiejszego wybryku nieobyczajnego z art. 142 ustawy z 20 maja 1971 r. - Kodeks wykroczeń (Dz.U. z 2018 r., poz. 618, dalej: k.w.; Budyn-Kulik, Kulik 2017, 796-797). W okresie dwudziestolecia międzywojennego, poza kodeksem karnym, prostytucja była regulowana również w innych aktach prawnych - w zasadniczej ustawie sanitarnej z dnia 19 lipca 1919 r. (Dz.Pr.P.P. z 1919 r. Nr 63, poz. 371), a także w rozporządzeniu Ministra Zdrowia Publicznego w porozumieniu z Ministrem Spraw Wewnętrznych z dnia 6 września 1922 r. o nadzorze nad nierządem (Dz.U. z 1922 r. Nr 78, poz. 715). Zgodnie z ówczesnymi przepisami prostytutki były objęte obligatoryjnymi kontrolami lekarskimi oraz wpisem do rejestru osób uprawiających nierząd zawodowo. Ponadto istniały komisje sanitarno-obyczajowe, które zajmowały się sprawami dotyczącymi nierządu oraz chorobami wenerycznymi. Sposób i zasady walki z tym procederem do wybuchu wojny nie zostały określone ustawowo. Również z powodu wojny nie doczekał się realizacji rządowy projekt ustawy o zwalczaniu nierządu z 1937 r. (Lipska-Toumi 2014, 242-243).

W Kodeksie karnym z 1969 r. znajdował się rozdział XXIII, zatytułowany „Przestępstwa przeciwko obyczajności”. Zgodnie z art. 174 k.k. z 1969 r. zachowanie związane z prostytucją objęte kryminalizacją to nakłanianie innej osoby do uprawiania nierządu, które było zagrożone karą pozbawiania wolności od roku do 10 lat. Sama prostytucja, zarówno homoseksualna, jak i heteroseksualna, nie była kryminalizowana.

Kodeks karny z 1997 r. również nie sankcjonuje uprawiania prostytucji. Prostytucja w Polsce jest legalna. Jej uprawianie może jednak pośrednio podlegać karze, zgodnie z art. 142 k.w., który sankcjonuje proponowanie innej osobie dokonania z nią czynu nierządnego, mając na celu uzyskanie korzyści materialnej, natarczywie, narzucając się lub w inny naruszający porządek publiczny sposób. Dobrowolne uprawianie prostytucji nie jest karalne, co wynika z ratyfikowanej przez Polskę abolicjonistycznej międzynarodowej Konwencji o zwalczaniu handlu ludźmi i eksploatacji prostytucji z dnia 21 marca 1950 r. (Dz.U. z 1952 r. Nr 41, poz. 278), zakazującej nie tylko penalizacji, ale również rejestracji prostytutek (Hypś 2018, 1051). Takie podejście należy uznać za słuszne, gdyż nie 
stygmatyzuje samych prostytutek, ale przewiduje karalność wszelkich form eksploatacji prostytucji przez osoby trzecie, czyli za: sutenerstwo - czerpanie korzyści z cudzego nierządu, stręczycielstwo - nakłanianie innej osoby do uprawiania prostytucji i kuplerstwo - czerpanie korzyści za ułatwianie prostytucji (Czerwonka 2012, 61). Należy jednak zwrócić uwagę na założenia, które legły u podstaw konwencji - prostytucja jest legalna, ale nie dlatego, że osoby świadczące usługi seksualne chcą je świadczyć. Opiera się na założeniu, że kobiety są niedorozwinięte umysłowo i nie mogą same o sobie decydować, są zatem zmuszane do tego procederu i nie mogą być za to karane - nie można bowiem karać kogoś, kto nie wie, co czyni (Welskop 2013, 6-7). Poza rozwiązaniami kodeksu karnego obecnie w polskim prawie nie ma jakiejkolwiek regulacji prawnej, która normowałaby kwestię zapobiegania prostytucji, handlowi kobietami oraz obowiązku terapii osób w ten sposób poszkodowanych. Są jedynie pośrednie rozwiązania, które nakładają na organy samorządu terytorialnego obowiązek przeciwdziałania patologiom społecznym ${ }^{1}$.

Można wyróżnić cztery modelowe systemy prawne w zakresie regulacji zjawiska prostytucji: prohibicjonizm, reglamentaryzm, neoreglamentaryzm, abolicjonizm.

Prohibicjonizm całkowicie zakazuje uprawiania prostytucji. W tym systemie jest ona uważana za przestępstwo. Regulacje prawne są skierowane wyłącznie do osób prostytuujących się, a nie do korzystających z tych usług. System ten był powszechny w Stanach Zjednoczonych na przełomie wieku XIX i XX (Charkowska 2010, 32). Prostytucja jest uważana za relację, która nie opiera się na zaufaniu $\mathrm{i}$ trosce, a jedynie na zaspokojeniu popędu seksualnego, a sprzedawanie własnego ciała jest uchybieniem własnej godności (Brożek i in. 2010, 182).

Model reglamentacyjny uznaje, iż nieprzymuszona prostytucja jest działalnością legalną, mającą status zawodu. Prostytucję wolno uprawiać tylko w domach publicznych, pod nadzorem służby sanitarnej i władz porządkowych. Osoby prostytuujące się zobligowane są do rejestracji oraz przechodzenia badań lekarskich. Jest to związane z tolerancją wobec tego zjawiska oraz uznaniem jego nieuchronności (tamże, 185).

W modelu neoreglamentacyjnym uprawianie prostytucji nie musi odbywać się w domach publicznych. Prostytutki są rejestrowane przez służby sanitarne i porządkowe. Muszą posiadać książeczki kontrolne z aktualnymi wynikami badań (Domańska 2017, 44).

Model abolicjonistyczny opiera się na założeniu, iż prostytucja nie jest zjawiskiem reglamentowanym prawnie, nie jest też wyraźnie zalegalizowana. Nie jest uznawana za zjawisko nielegalne przy równoczesnej wiedzy o jej powszechności

${ }^{1}$ Tak na przykład: Ustawa o wychowaniu w trzeźwości i przeciwdziałaniu alkoholizmowi z dnia 26 października 1982 r. (Dz.U. z 2016 r., poz. 487 ze zm.), Ustawa o pomocy społecznej z dnia 12 marca 2004 r. (Dz.U. z 2017 r., poz. 1769), Ustawa o przeciwdziałaniu narkomanii z dnia 29 lipca 2005 r. (Dz.U. z 2017 r., poz. 783 ze zm.). 
i konsekwencjach. Prostytucja sama w sobie nie jest sankcjonowana prawnie, ale społecznie poprzez stygmatyzację (Brożek i in. 2010, 184). Podstawowe założenia abolicjonizmu opierają się na pracy profilaktycznej, wszechstronnej reedukacji prostytutek oraz sankcjonowaniu czynów związanych z czerpaniem korzyści z prostytucji (Krawczyńska 2006, 11). System ten przeciwdziała prostytucji w sposób pośredni, gdyż podejmuje walkę nie z samym zjawiskiem, ale zajmuje się warunkami sprzyjającymi powstawaniu prostytucji oraz ułatwianiu jej uprawiania (Charkowska 2010, 34). W Polsce funkcjonuje model abolicjonistyczny. Zakłada on aktywne działanie zarówno ustawodawcy, jak i organów państwa w zwalczaniu przyczyn prostytucji oraz niwelowaniu jej skutków. Ustawodawca „zdaje sobie sprawę" z tego, że zjawisko prostytucji funkcjonuje i godzi się na to, pozostając obojętnym na skutki i przyczyny, jakie ono wywołuje. Przyjęte konstrukcje prawne są na tyle nieprecyzyjne, że umożliwiają działanie agencji towarzyskich poza jakąkolwiek kontrolą państwa. Trafnym rozwiązaniem byłoby sięgnięcie do kodyfikacji z okresu dwudziestolecia międzywojennego - rozpoznawszy zagrożenia i konsekwencje zjawiska prostytucji, starano się im zapobiec lub je zniwelować poprzez działania profilaktyczne. Przekonanie, że prostytucję można zwalczyć odpowiednimi regulacjami prawnymi, jest przejawem tzw. błędu moralistycznego, oznaczającego, iż system prawny powinien zawierać takie reguły, których spełnienie jest możliwe. Jak pokazuje historia, prostytucja jest nieuchronna, gdyż stanowi zastępcze środowisko realizacji popędu płciowego. Kanalizuje popęd płciowy osób, który miałby negatywne skutki, gdyby nie został zaspokojony (Brożek i in. 2010, 186). Nie można jej zwalczyć, ale należy i można ją uzdrowić poprzez kompleksowe działania interdyscyplinarne z zakresu psychologii, socjologii, medycyny oraz prawa. Profilaktyka jest odpowiedzią na współczesne zjawisko prostytucji.

Skoro prostytucji nie da się zlikwidować, to czy można ją zalegalizować? Prostytucja nie została w Polsce prawnie zatwierdzona jako forma działalności świadczonej na rzecz innych osób. Nie może więc być przedmiotem umowy w stosunku pracy ani umowy cywilnoprawnej. $Z$ tego powodu używa się określenia agencja towarzyska, tzn. oferująca (płatne) usługi towarzyskie, za czynności seksualne bowiem nie można legalnie żądać zapłaty. Ponadto prostytucja nie jest traktowana w Polsce jak każde inne zajęcie, ale jako stygmatyzujące, niemoralne. Jak podkreśla Joanna Sztobryn-Giercuszkiewicz, ze względu na konsekwencje zdrowotne traktowanie prostytucji jak każdego innego zawodu może wydać się kontrowersyjne, gdyż komercyjne uprawianie seksu można uznać za jedną z najbardziej wyniszczających form działalności człowieka, zarówno w sferze psychicznej, jak i fizycznej (Sztobryn-Giercuszkiewicz 2004, 113). Należy zatem rozważyć plusy i minusy wynikające $\mathrm{z}$ objęcia $\mathrm{w}$ ramy regulacji prawnych zjawiska prostytucji. Po pierwsze, wprowadzenie kompleksowego systemu sanitarno-medycznego (obligatoryjne badania, książeczki zdrowia, akcje informacyjne dotyczące profilaktyki zdrowotnej, punkty poradnictwa medycznego) będzie sprzyjało zwiększeniu bezpieczeństwa rynku usług seksualnych. Po drugie, możliwa będzie skuteczniejsza 
walka z handlem ludźmi. Po trzecie, osoby świadczące usługi seksualne uzyskałyby prawa pracownicze - opłacałyby składki emerytalne, rentowe oraz posiadałyby ubezpieczenie. Obrazując negatywne konsekwencje legalizacji prostytucji, warto przytoczyć pogląd Janice G. Raymond, która wskazuje, iż „wiele osób wierzy, że występując na rzecz legalizacji lub dekryminalizacji prostytucji, uszlachetniają i profesjonalizują kobiety pracujące $\mathrm{w}$ prostytucji. Jednak uszlachetnienie prostytucji jako zawodu nie oznacza uszlachetnienia kobiet - uszlachetnia się po prostu seksbranżę!”. Autorka podaje, że legalizacja przyczyni się do wzmocnienia negatywnych konsekwencji prostytucji, do rozrostu seksbiznesu, wzmożenia handlu żywym towarem, rozrostu podziemnej prostytucji i prostytucji ulicznej, zachęci do „kupowania” kobiet w prawnie przyzwolony sposób i tym samym do ich, jeszcze większego, uprzedmiotowienia (Raymond 2006, 52-57). Legalizacja prostytucji sygnalizowałaby społeczeństwu, że człowiek jest towarem wielokrotnego użycia, a prostytucja to nieszkodliwa zabawa. Ponadto samo środowisko osób świadczących usługi seksualne także niechętnie wypowiada się na temat legalizacji prostytucji - nie chcą mieć dodatkowego sutenera w postaci państwa (Charkowska 2010, 74).

\section{PODSUMOWANIE}

Seksualność jako immanentny element ludzkiej osobowości jest związana z popędem seksualnym $i$ jego realizacją. Jedną $\mathrm{z}$ form tej realizacji jest prostytucja, która wówczas, gdy mieści się w określonych ramach, nie jest szkodliwa, czyli - jeśli ludzie wiedzą, co czynią, zgadzają się na to, nikt, albo przynajmniej nikt poza uczestniczącymi w aktywności, nie jest poszkodowany. Prostytucja jednak prawie zawsze niesie ze sobą szkodę i spustoszenie - zarówno fizyczne, jak i psychiczne - dla osób świadczących usługi seksualne oraz dla osób z nich korzystających. Trudno również określić, kiedy świadczenie takich usług jest świadomym wyborem drogi życiowej, a kiedy przymusem wynikającym z potrzeby szybkiego uzyskania środków pieniężnych. Jak pokazuje historia, zjawisko prostytucji było, jest i będzie elementem społeczeństwa dopóki istnieje popyt. Zamykanie oczu na przyczyny i konsekwencje przy równoczesnej stygmatyzacji tego zjawiska, jest o wiele bardziej szkodliwe. Prostytucja przedstawiana jest jako patologia społeczna, zjawisko oswojone w zbiorowych wyobrażeniach jako „najstarszy zawód świata", niemożliwe do usunięcia z życia zbiorowego, a przy tym niemoralne i szkodliwe. W dobie seksualizacji przestrzeni publicznej, w której nagość i seks są obecne oraz powszechnie akceptowane, trudno umiejscowić prostytucję i jednoznacznie ją ocenić. Jak trafnie wskazuje Katarzyna Charkowska, zarówno polski kodeks karny, jak i moralne przekonanie społeczeństwa opierają się na podobnym założeniu - nie mogąc zabronić prostytucji, potępiają ją (tamże, 32). Refleksja nad zjawiskiem prostytucji jest w istocie refleksją na temat człowieka 
i jego seksualności we współczesnym świecie - świecie dynamicznych przemian, zaniku relacji więziotwórczych, relatywizmu moralnego, osamotnienia. Jednoznaczna ocena prostytucji jest bardzo trudna ze względu na złożoność zjawiska i jego kontrowersyjność. $Z$ jednej strony jest to konieczność, a $z$ drugiej - przejaw zamrożonej moralności. Zjawisko prostytucji, podobnie jak tematyka statusu prawnego mniejszości seksualnych, generuje negatywne emocje społeczne, które następnie rodzą stereotypy i uprzedzenia, tworzące nieprzekraczalną barierę dla debat. Wynika to m.in. z braku edukacji seksualnej i niewiedzy na temat seksualności człowieka. Odpowiedzią na współczesne zjawisko prostytucji jest rzetelna edukacja oraz profilaktyka.

\section{BIBLIOGRAFIA}

Brożek, Bartosz, Wojciech Załucki, Marta Soniewicka, Jerzy Stelmach. 2010. Paradoksy bioetyki prawniczej. Warszawa: Wolters Kluwer.

Budyn-Kulik, Magdalena, Marek Kulik. 2017. „Komentarz do art. 203”. W Kodeks karny. Część szczególna. T. 1: Komentarz do artykułów 117-221. Red. Michał Królikowski, Robert Zawłocki. 795-801. Warszawa: Wydawnictwo C.H. Beck.

Charkowska, Katarzyna. 2010. Zjawisko prostytucji w doświadczeniach prostytuujacych się kobiet. Kraków: Oficyna Wydawnicza Impuls.

Czerwonka, Agata. 2012. „Przestępstwo zmuszania do prostytucji”. Ius Novum 1: 61-75.

Dec-Pietrowska, Joanna, Agnieszka Walendzik-Ostrowska. 2014. „Kobieta «upadła» - o stereotypowym postrzeganiu kobiet świadczących usługi seksualne. Analiza forów internetowych". Dyskursy Młodych Andragogów 15: 295-309.

Domańska, Joanna M. 2017. „Zjawisko prostytucji - analiza teoretyczna”. Edukacja Humanistyczna 1 (36): 33-48.

Gardian-Miałkowska, Renata. 2013. „(Nie)bezpieczeństwo świadczenia usług seksualnych. Świadomość ryzyka i konsekwencji pracy w sex-biznesie na przykładzie doświadczeń mężczyzn uwikłanych w prostytucję”. Profilaktyka Społeczna i Resocjalizacja 22: 131-152.

Hypś, Sławomir. 2018. „Komentarz do art. 204”. W Kodeks karny. Komentarz. Red. Alicja Grześkowiak, Krzysztof Wiak. 1051-1054. Warszawa: Wydawnictwo C.H. Beck.

Imieliński, Kazimierz. 1990. Manowce seksu - prostytucja. Łódź: Res Polona.

Krajewski, Radosław. 2012. „Zgwałcenie osoby trudniącej się prostytucją”. Ius Novum 2: 61-72.

Krawczyńska, Marta. 2006. „Kuplerka, sutener, stręczycielstwo”. Prawo i Pteć 8: 10-15.

Lipska-Toumi, Małgorzata. 2014. Polskie prawo wobec zjawiska prostytucji w latach 1918-1939. Lublin: Wydawnictwo KUL.

Nelson, Todd D. 2003. Psychologia uprzedzeń. Gdańsk: Gdańskie Wydawnictwo Psychologiczne.

Płatek, Monika. 2014. „Genderowe ujęcie zjawiska prostytucji. Aspekty kryminologiczne”. W Prostytucja. Red. Marek Mozgawa. 226-256. Warszawa: Wolters Kluwer.

Poznańska, Wanda Maria. 2005. „Prostytucja”. W Encyklopedia pedagogiczna XXI wieku. T. 4. Red. Tadeusz Pilch. 995-996. Warszawa: Wydawnictwo Akademickie Żak.

Raymond, Janice. G. 2006. „10 powodów, by nie legalizować prostytucji (i prawna odpowiedź na popyt na prostytucję". Prawo i Pteć 8: 52-59.

Schaff, Adam. 1989. Stereotypy a działanie ludzkie. Warszawa: Książka i Wiedza.

Stangor, Charles, Mark Schaller. 1999. „Stereotypy jako reprezentacje indywidualne i zbiorowe”. W Stereotypy i uprzedzenia. Najnowsze ujęcie. Red. Neil Macrae, Charles Stangor, Miles 
Hewstone. Tł. Agnieszka Nowak, Anna Kacmajor, Magdalena Kacmajor, Małgorzata Majchrzak. 13-36. Gdańsk: Gdańskie Wydawnictwo Psychologiczne.

Sztobryn-Giercuszkiewicz, Joanna. 2004. Psychologiczne aspekty prostytucji. Łódź: Dajas.

Walendzik-Ostrowska, Agnieszka. 2006. „Kilka mitów o prostytucji”. Prawo i Płeć 8: 35-39.

Warylewski, Jarosław. 2015. „Komentarz do art. 203”. W Kodeks karny. Komentarz. Red. Ryszard A. Stefański. 1278-1283. Warszawa: Wydawnictwo C.H. Beck.

Welskop, Wojciech. 2009. „Wykluczenie prostytutek z dyskursu społecznego. Sytuacja formalno-prawna zjawiska prostytucji w Polsce”. Pro Publico Bono 5: 225-233.

Welskop, Wojciech. 2013. Zjawisko prostytucji w Polsce po 1989 roku. Toruń: Wydawnictwo Europejskie Centrum Edukacyjne.

\title{
Orzecznictwo
}

Wyrok SN z dnia 7 czerwca 1971 r., sygn. II KR 86/71, LEX nr 21408.

\section{Akty prawne i materiały legislacyjne}

„Instrukcja dla lekarzy i urzędników urzędów i punktów sanitarno-obyczajowych z dnia 4 kwietnia 1919 r.”. 1919. Monitor Polski. Dziennik Urzędowy Rzeczypospolitej Polskiej 107: 2-3. http:// orzecznictwo.org/wp-content/uploads/2016/07/716213.pdf [dostęp 20.02.2018].

Konwencja w sprawie zwalczania handlu ludźmi i eksploatacji prostytucji z dnia 21 marca 1950 r. (ratyfikowana na podstawie ustawy z dnia 29 lutego 1952 r. - Dz.U. Nr 13, poz. 78) (Dz.U. z 1952 r. Nr 41, poz. 278).

Rozporządzenie Prezydenta Rzeczypospolitej Polskiej z dnia 11 lipca 1932 r. - Kodeks karny (Dz.U. z 1932 r. Nr 60, poz. 571 ze zm.).

Rządowy projekt ustawy o zwalczaniu nierządu, druk nr 598. https://bs.sejm.gov.pl/exlibris/aleph/ a22_1/apache_media/4CPEDB6T6KGIBTGYHBJUYYU4B3S8YL.pdf [dostęp 20.02.2018].

Ustawa z dnia 19 kwietnia 1969 r. - Kodeks karny (Dz.U. z 1969 r. Nr 13, poz. 94 ze zm.).

Ustawa z dnia 20 maja 1971 r. - Kodeks wykroczeń (Dz.U. z 2015 r., poz. 1094 ze zm.).

Ustawa z dnia 6 czerwca 1997 r. - Kodeks karny (tekst jedn. Dz.U. z 2017 r., poz. 2204 ze zm.).

Zasadnicza ustawa sanitarna z dnia 19 lipca 1919 r. (Dz.U. z 1919 r. Nr 63, poz. 371 ze zm.).

\author{
Marlena Drapalska-Grochowicz
}

\section{PHENOMENON OF PROSTITUTION - BETWEEN NECESSITY AND TABOO?}

\begin{abstract}
Prostitution is a phenomenon that evokes extreme emotions in the discourse. Stereotypes and myths in which the phenomenon of prostitution has outgrown dwarf the real picture of this phenomenon. Nowadays, the most important issue is a reflection on causes and consequences of this phenomenon. The phenomenon of prostitution puts to the test traditional concepts defining human sexuality - what its limits are and how to separate what falls within socially acceptable norms and what does not. Prostitution, on the one hand, appears as a necessity and on the other hand as a safety valve for the society. The ambiguity of the phenomenon of prostitution is illustrated by doubts around the legalisation on prostitution.
\end{abstract}

Keywords: prostitution, stereotypes, legalization of prostitution, sex services, sexual education. 